\title{
Clinical relevance of ANCA in small-vessel vasculitis
}

Citation for published version (APA):

Damoiseaux, J., \& Bossuyt, X. (2018). Clinical relevance of ANCA in small-vessel vasculitis: positioning of antigen-specific immunoassays. Clinical Rheumatology, 37(7), 2015-2016.

https://doi.org/10.1007/s10067-018-4154-7

Document status and date:

Published: 01/07/2018

DOI:

10.1007/s10067-018-4154-7

Document Version:

Publisher's PDF, also known as Version of record

Document license:

Taverne

Please check the document version of this publication:

- A submitted manuscript is the version of the article upon submission and before peer-review. There can be important differences between the submitted version and the official published version of record.

People interested in the research are advised to contact the author for the final version of the publication, or visit the DOI to the publisher's website.

- The final author version and the galley proof are versions of the publication after peer review.

- The final published version features the final layout of the paper including the volume, issue and page numbers.

Link to publication

\footnotetext{
General rights Owners
rights.

- You may freely distribute the URL identifying the publication in the public portal. please follow below link for the End User Agreement:

www.umlib.nl/taverne-license

Take down policy

If you believe that this document breaches copyright please contact us at:

repository@maastrichtuniversity.nl

providing details and we will investigate your claim.
}

Copyright and moral rights for the publications made accessible in the public portal are retained by the authors and/or other copyright owners and it is a condition of accessing publications that users recognise and abide by the legal requirements associated with these

- Users may download and print one copy of any publication from the public portal for the purpose of private study or research.

- You may not further distribute the material or use it for any profit-making activity or commercial gain

If the publication is distributed under the terms of Article $25 \mathrm{fa}$ of the Dutch Copyright Act, indicated by the "Taverne" license above, 


\title{
Clinical relevance of ANCA in small-vessel vasculitis: positioning of antigen-specific immunoassays
}

\author{
Jan Damoiseaux ${ }^{1}$ D $\cdot$ Xavier Bossuyt $^{2,3}$ \\ Received: 2 May 2018 / Accepted: 15 May 2018 / Published online: 25 May 2018 \\ (C) International League of Associations for Rheumatology (ILAR) 2018
}

To the editor:

In a recent publication of Suwanchote et al. in Clinical Rheumatology [1], the clinical significance of anti-neutrophil cytoplasmic antibodies (ANCA) is reviewed for a broad spectrum of ANCA-associated diseases, including small-vessel vasculitis and diseases of the gastro-intestinal tract.

The authors put forward indirect immunofluorescence (IIF) as a method for ANCA screening. In the paragraph describing granulomatosis with polyangiitis (GPA), the authors state that "a positive ANCA test (particularly c-ANCA) strongly supports the diagnosis" and in the paragraph related to microscopic polyangiitis, the authors state that "most patients are positive for p-ANCA." Although these statements are correct, they do not give credit to the importance of the determination of the antigen specificity [proteinase 3 (PR3)-ANCA versus myeloperoxidase (MPO)-ANCA].

There is increasing evidence that support the idea that ANCA-associated vasculitis can be classified on the basis of the ANCA subtype [reviewed in 2]. PR3-ANCA and MPOANCA are associated with different epidemiological, genetic, and disease phenotype features as well as with response to therapy, relapse risk, and prognosis [2]. Such newly proposed classification by ANCA specificity allows for immediate diagnosis [2].

In line with the abovementioned insights on ANCA subtype, and supported by a large multicenter study that evaluated

Jan Damoiseaux

jan.damoiseaux@mumc.nl

1 Central Diagnostic Laboratory, Maastricht University Medical Center, P. Debyelaan, 6229 HX Maastricht, The Netherlands

2 Department of Microbiology and Immunology, University of Leuven, Leuven, Belgium

3 Department of Laboratory Medicine, University Hospitals Leuven, Leuven, Belgium the performance of immunoassays and IIF [3-5], a revision of the consensus recommendations on ANCA testing for smallvessel vasculitis has been published [6]. These revised consensus recommendations state that high-quality antigen-specific immunoassays for PR3-ANCA and MPO-ANCA are the preferred screening methodology for the diagnosis of ANCAassociated vasculitis [6].

These new developments in ANCA testing for small-vessel vasculitis were overlooked in the paper of Suwanchote et al.

\section{Compliance with ethical standards}

Disclosures None.

\section{References}

1. Suwanchote S, Rachayon M, Rodsaward P, Wongpiyabovorn J, Deekajorndech T, Wright HL, Edwards SW, Beresford MW, Rerknimitr P, Chiewchengchol D (2018) Anti-neutrophil cytoplasmic antibodies and their clinical significance. Clin Rheum 37:875884

2. Cornec D, Cornec-Le Gall E, Fervenza FC, Specks U (2016) ANCAassociated vasculitis - clinical utility of using ANCA specificity to classify patients. Nat Rev Rheumatol 12:570-579

3. Csernok E, Damoiseaux J, Rasmussen N, Hellmich B, van Paassen P, Vermeersch P, Blockmans D, Cohen Tervaert JW, Bossuyt X (2016) Evaluation of automated multi-parametric indirect immunofluorescence assays to detect anti-neutrophil cytoplasmic antibodies (ANCA) in granulomatosis with polyangiitis (GPA) and microscopic poltyangiitis (MPA). Autoimmun Rev 15:736-741

4. Damoiseaux J, Csernok E, Rasmussen N, Moosig F, van Paassen P, Baslund B, Vermeersch P, Blockmans D, Cohen Tervaert JW, Bossuyt X (2017) Detection of antineutrophil cytoplasmic antibodies (ANCAs): a multicenter European Vasculitis Study Group (EUVAS) evaluation of the value of indirect immunofluorescence (IIF) versus antigen-specific immunoassays. Ann Rheum Dis 76:647-653

5. Bossuyt X, Rasmussen N, van Paassen P, Hellmich B, Baslund B, Vermeersch P, Blockmans D, Cohen Tervaert JW, Csernok E, Damoiseaux J (2017) A multicenter study to improve clinical interpretation of proteinase- 3 and myeloperoxidase anti-neutrophil cytoplasmic antibodies. Rheumatology 56:1533-1541 
6. Bossuyt X, Cohen Tervaert JW, Arimura Y, Blockmans D, Flores-Suárez LF, Guillevin L, Hellmich B, Jayne D, Jennette JC, Kallenberg CGM, Moiseev S, Novikov P, Radice A, Savige JA, Sinico RA, Specks U, van Paassen P, Zhao M,
Rasmussen N, Damoiseaux J, Csernok E (2017) Revised 2017 international consensus on testing of ANCAs in granulomatosis with polyangiitis and microscopic polyangiitis. Nat Rev Rheum 13:684-692 